3. Народні прислів'я та приказки / Упорядкування та передмова Миколи Дмитренка. - К. : Редакція часопису «Народознавство», 1999. - 180с.

4. Сом, М. «Вмирати вмирай, а жито сій» / Микола Сом // Літературна Україна. 2012. - 24 травня.

5. Стельмах, М. Гуси-лебеді летять : повість / Михайло Стельмах. - К. : Веселка, 1966. $-158 \mathrm{c}$.

Стаття надійшла 17.03.2016 року

УДК 821. 161. 2 (091)“18/19”

Леся Полішук, Олена Наконечна

(Умань, Україна)

\title{
ЕЛЕМЕНТИ ІМПРЕСІОНІСТИЧНОГО ПИСЬМА У ПРОЗІ В. ЛЕОНТОВИЧА ПЕРІОДУ ЕМІГРАЦЇ̈
}

Метою статті є дослідження художніх особливостей індивідуальної стильової манери прози В.Леонтовича періоду еміграції, яку можна кваліфікувати як неореалістичну, таку, що несе в собі риси модерністських тенденцій, зокрема вкраплення імпресіоністичних способів художнього зображення.

Ключові слова: В. Леонтович, світоглядні позиції, моделювання дійсності, повість, реалізм, імпресіонізм, психологія персонажа.

Полищук Л., Наконечная Е. Элементы импрессионистического письма в прозе В. Леонтовича периода эмиграции.

Целью статьи является исследование художественных особенностей индивидуальной стилевой манеры прозы В. Леонтовича периода эмиграчии, которую можно квалифицировать как неореалистическую, несущую в себе черты модернистских тенденций, в частности вкрапления импрессионистических способов художественного изображения.

Ключевые слова: В. Леонтович, мировоззренческие позиции, моделирования действительности, повесть, реализм, импрессионизм, психология персонажа.

Polishchuk L., Nakonechna O. Elements of impressionistic writing prose V. Leontovych period of emigration.

In the work of the elderly literary generation (I. Franko, P. Mirny, I. Nechuy-Levitsky, $O$. Konysky), in younger writers prose who continued the realistic tradition of the late XIXearly XX centuries (S. Kovaliv, T. Bordulyak, A. Chaykovskyj, A. Teslenko) the significant updates can be seen that is one of the main features of the literary situation in the end of the XIX century. Among the varied prose genre varieties there are works that are noticeably different from the traditional realistic writing. $V$. Leontovych readily perceived his contemporaries and modernists innovations, as a well-established traditionalist. He tended to recess into the inner man's world that had the impact on the poetics of his works at the turn of the century. It is necessary to note the presence of all-in-one features impressionistic poetics system that particularly brightly manifested in such works as «Ворохобня», «Гинуть мрї̈,, «Дитячі і юнаџькі роки Володі Ганкевича». Among these features, the landscapes outlined in impressionistic manner, attention to detail, bright events, colorful 
impressionistic language should be pointed out firstly. Thus the analysis of $V$. Leontovych creative works in the period of emigration allows to draw conclusions about a gradual evolution from realistic to impressionistic style of writing.

Keywords: V. Leontovich, ideological positions, modeling reality genre story, realism, impressionism, psychology of the character.

У творчості письменників кінця XIX - початку XX століть простежується суттєве оновлення. Реалізм, як мистецький напрям на межі століть набуває нових рис, помітно еволюціонуючи в аспекті збагачення та ускладнення тематики, проблематики та посиленого інтересу до формальних чинників твору. На початку XX століття формується новий тип психологізму - відмінний від психологізму Панаса Мирного та I. Франка. Передусім цим характеризується творчість представників нової школи в белетристиці - М. Коцюбинського, В. Стефаника, О. Кобилянської, М. Яцківа та ін. Це було однією 3 прикмет загальної тенденції оновлення художнього мислення доби. Твори письменників старшого покоління стають лаконічнішими, в них менше уваги надається описам i деталізації побутових обставин і поряд 3 цим поглиблюється інтерес до індивідуально-особистісного начала, психологізації персонажа. Ці ідейно-естетичні пошуки найчастіше трансформувалися у прагнення письменників зрозумілі закономірності реальної дійсності доповнити інтересом до прихованих процесів розвитку внутрішнього світу людини.

I. Франко тонко помітив зміни в психологічному аналізі, що відбувалися в українській літературі на зламі століть, зокрема: конкретні факти життя зображуються менше; майже вся увага письменників переноситься на особистість, значною мірою на піi внутрішній світ. Людина постає перед читачем як самостійна, «суверенна» цінність, окремішність (Леся Українка), як особистість зі «складною душевною організацією» [2, с. 17]. «Проте, - відзначає Ю. Кузнєцов, - обставини, їх незалежний історичний розвиток для митців такою ж мірою важливі, як $\mathrm{i}$ сам герой» [2, с. 17]. Осмислення екзистенційних проблем не послабило в українських письменників прагнення розв'язувати життєво важливі для українського народу питання про місце України в системі народнодержавних i мистецьких цінностей, що $є$ природним для справжнього письменника.

Представник українського письменства кінця XIX - початку XX століття - В. Леонтович, подібно до інших представників модерної літератури, зазнав чималого впливу європейської філософської думки, що й призвело його як до тематичної переорієнтації, так і до зміни способів проникнення у внутрішній світ особистості. Творче осмислення здобутків західної культурно-естетичної думки дало змогу письменникові поєднати загальну народницьку парадигму творчості 3 використанням модерних художніх засобів, властивих творам модерністів. Саморефлексії 
персонажів Леонтовичевої прози не просто засвідчують тяжіння белетриста до новаторських прийомів психологічного аналізу, але й виступають творчим втіленням глибокого життєво-пізнавального сенсу його творів «Вигнанці», «Спомини втікача», «Ворохобня», «Дитячі i юнацькі роки Володі Ганкевича».

Таким чином, особливої актуальності набуває потреба нового прочитання раніше аналізованих творів В. Леонтовича і введення до широкого вжитку цілого ряду нових, ще не інтерпретованих текстів та досить значного обсягу матеріалів біографічного характеру.

Імпресіоністичне світовідчуття від своєї появи в українській літературі викликало протилежні оцінки. Їх широкий діапазон засвідчував неоднозначність імпресіонізму як художньо-мистецького явища. Пояснювалося це, насамперед, самою природою імпресіоністичного світовідчуття, іii орієнтацією на враження, пропозицією реципієнтові доосмислити реальність. Критики традиційної ідейно-естетичної орієнтації вважали це недопустимим бунтом проти самих засад мистецтва. Слід відзначити також, що така оцінка була характерною і для інших літератур європейських народів. Навіть у Франції - батьківщині імпресіонізму - ставлення до його появи було досить ворожим. Це пояснювалося тим, що тогочасне європейське суспільство в переважній своїй більшості було виховане на засадах традиційного реалізму, що заважало йому адекватно сприйняти назрілі новації імпресіоністів. Пропаговане імпресіоністами право митця на суб' єктивне бачення світу і небажання зв'язувати своє бачення предмета обов'язковими нормами об‘єктивного письма, властивого реалізму, видавалися критиці нечуваною зухвалістю, вступом у конфлікт з уже існуючою художньою практикою, бо заперечувало загальноприйняті тоді у мистецтві категорії. Саме цим i пояснюється опозиція суспільної та літературно-критичної думки імпресіонізмові як потужній новації в естетиці белетристики. Орієнтація на індивідуальність, а згодом організований теоретичний розгром українського літературного процесу, пануюча ідеологія до деіндивідуалізації людської особистості, принесення суб'єктивного бачення світу в жертву колективізму, виведення ідей статизму та русифікації на одне 3 чільних місць в радянській ідеології зашкодили імпресіонізмові. 3 цих причин довгий час об' єктивне й неупереджене дослідження форм виявлення імпресіоністичного світобачення й поетики було неможливим. I лише останнім часом 3'являються праці, у яких фундаментально осмислюється саме явище українського модерну i зокрема, однієї з його течій - імпресіонізму Це перш за все роботи Т. Гундорової «Проявлення слова», С. Павличко «Дискурс раннього модернізму», В. Агеєвої «Рання імпресіоністична проза», праці 
С. Пригодія, Г. Сіпаки тощо. У цьому ж дискурсі маємо за мету дослідити прояви імпресіоністичного світобачення митця В. Леонтовича.

Найбільш повно імпресіонізм як художньо-стильова течія виявився в творчості М. Коцюбинського. Водночас певні елементи імпресіоністичної поетики також простежуються у творчості А. Головка, М. Хвильового, М. Івченка, Ю. Яновського, Г. Михайличенка, М. Сріблянського, у багатьох інших художників слова.

У творчому доробку В. Леонтовича імпресіонізм як літературне явище не є художньою практикою. У його прозі простежується така світоглядна риса імпресіонізму, як прагнення не стільки щось зобразити, скільки викликати у читача емоційно сильне враження.

Відповідно до однієї з головних засад імпресіоністичної поетики, В. Леонтович відмовляється від художньої типізації, постійно акцентуючи увагу читачів на винятковості вчинків персонажа (Опанаса Порубайката «Ворохобня», Володі Ганкевича «Дитячі і юнацькі роки Володі Ганкевича»). Саме прагнення детально й містко змоделювати найтонші порухи душі людини дали підстави Ф. Погребеннику вважати, що «проза В. Леонтовича загалом належить до надбань реалістично-побутової школи, але в непоодиноких новелах та оповіданнях відчуваємо тяжіння до імпресіоністичної манери письма, заглиблення у внутрішній світ людини, нахил до лаконізму та експресивності у викладі думки, змалюванні явищ життя» [8, с. 7].

На думку В. Агеєвої, «однією з чільних засад імпресіоністичної світоглядної системи є віра в те, що навколишній світ дано людині в її відчуттях. Тим самим передача конкретних вражень від того чи іншого окремого образу, сприйнятого митцем, дозволяє йому досягти нічим не спотвореної правди життя» [1, с. 8]. Фіксація вражень, почувань, які безпосередньо сприймаються художником, відкриває широкий простір для вияву суб' єктивного начала в людині. Імпресіонізм у живописі і в літературі висував на перший план духовність письменника, його особистісність. Мистецтво стає індивідуалізованим, відтворюючи красу й розмаїтість життя крізь призму сприймання його окремою особистістю.

У творах В. Леонтовича «Дитячі і юнацькі роки Володі Ганкевича», «Вигнанці», «Гинуть мрії», “Ворохобня» виявляються риси імпресіоністичного способу моделювання дійсності. В інших художніх текстах - «Помирили», «Лубні», «Vis majer», «Спомини втікача», переважає такий опис, розповідь, зображення, у якому слово активізується, функціонує як актуальна манера реалістичного образотворення та характеротворення. Проте й за цих умов імпресіоністичний ефект не тільки не зникає, а навпаки допомагає повніше втілити авторську ідею, вирізнити головний мотив чи настрій персонажа в художньому тексті. Такі твори ніби назовні увиразнюють 
справжню, часом навіть трагічну сутність певних реалій довколишнього життя, акцентуючи увагу читача на глибоких проблемах.

Поєднання рис імпресіоністичної стилістики з рисами традиційного для реалізму побутописання становить домінанту поетики деяких знакових творів В. Леонтовича. Імпресіоністичний вплив відчутний, зокрема, в такому творі, як «Дитячі і юнацькі роки Володі Ганкевича», в якому автор прагне передати згадку про щось незначне, про події, які, здавалося б, не могли загострити враження, почуттєву сферу читачів, їхню пам'ять. Письменник прямо сигналізує про спогади з дитинства хлопчика як про типову творчу манеру саме письменників-імпресіоністів: «Самий вигляд няньчин - маленька, суха, похилена, 3 обличчям густо покресленим зморшками тьмяно уявлявся йому, як бува на малюнку сучасних митців: перше враження наче нагадує змальовану річ, наче подібне до неї, але подробиці затерлися або змазалися» [3, с. 4]. Отже, В. Леонтович досить чітко засвідчує своє прагнення наблизити поетику повісті до манери «сучасних митців», основа світовідчуття якої спирається перш за все на враженнях від дій людини, від предмета, явища. У тексті твору міститься, хоча й не досить послідовно, виражене автором відтворення різних психологічних станів героя, аналіз їхніх проявів в окремих життєвих ситуаціях: «Здивований оглянувся довкола, зазирнув у найближчі кущі, і враз почув себе моторошно. Ще не злякався, але відчув неспокій і пішов з цієї зачарованої пущі. Злякався дужче, як уже вийшов 3 неї» $[3$, с. 6].

Письменник здійснює глибокий психологічний аналіз особистості героя, який часом не вписується в оточення, відчуває душевний дискомфорт саме через свою глибоку несхожість 3 іншими - за етичними чи суто психологічними ознаками. Персонажі свідомо акцентують на своїй індивідуальній сутності. Наприклад, таке явище простежується у творі «Ворохобня»: «Лютість за свою долю пече. Мусить же хтось за неї винен бути, що така ледача. Хто, не знаю, та певне вже ті, кого так звик ненавидіти» [4, с. 37].

Така типова заповненість внутрішнього світу персонажів вимагала від них і деяких особливих засобів моделювання дійсності. Поєднання подій i колізій відповідало орієнтації імпресіоністичної поетики на створення в читачів враження невідібраності, невпорядкованості твору.

Автор вдається до таких засобів психологічного аналізу, коли внутрішній світ персонажів досліджується через точну фіксацію, розмежування напівтонів настрою, нюансів психічних реакцій.

У наведених зовнішніх формах вияву особи криється дуже важливий вимір - психодуховний; він полягає в усвідомленні героєм сенсу буття взагалі і його власного. Зауважимо, що, наприклад, В. Франкл сенс людського буття вбачав у якнайвищій відповідальності індивідуума перед 
собою, перед своїм життям, кваліфікував цей сенс як домінанту, «місію» особи. Відповідальність у наведених словах окреслюється в найширшому розумінні - перед собою, суспільством, історією. Неможливість здійснення такого сенсу життя постає як велична внутрішня трагедія людини у світі, в тому середовищі, в якому вона не може реалізувати себе.

Особливого художнього забарвлення у творах В. Леонтовича набуває пейзаж. Він співзвучний художньому способові зображення пейзажу імпресіоністами, для яких пейзаж стає дієвим творчим засобом психологічної характеристики.

Подібно до манери прямого наслідування, характерного для французьких митців-імпресіоністів - по можливості незвичайно передавати своє враження від природи, В. Леонтович створює яскраві, колоритні пейзажі, зокрема, в повісті «Дитячі і юнацькі роки Володі Ганкевича»: «Дві високі розлогі черемшини, облиті, як молоком, китицями білих квіток, сповняли повітря солодкими пахощами» [3, с. 4]. Зосереджує увагу автор i на передачі вражень героя від природи: «Спинився, зачарований буянням життя, що його відчував у всьому: в траві, в деревах, у гудінні бджіл, у тріпотінні крилець метеликів» [3, с. 5]. Автор відтворює лише загальне уявлення про природу, відчуття від неї - $\mathrm{i}$ разом з тим своє власне та своїх героїв.

Письменник використовує художні образи «пишного саду», «місячної ночі», «місяця» для відтворення враження від навколишнього життя (i свого власного). У відтворенні такого пейзажу багато недомальованості, неясності, що, однак, вдало відтворює атмосферу непевності, невизначеності: «I тиша, і невиразне шамотіння, і таємниче освітлення ночі - все дратує стурбовану людину, відбирає спокій, ворушить чуття, здіймає сумніви» [3, с. 32].

Спроба створення психологічного пейзажу досить типова для модерністської естетики, через що й пейзаж в оповіданні створюється, здебільшого, засобами, притаманними авангардовій естетиці.

Враження слугує однією 3 основних ознак імпресіоністичного відтворення світу в художньому творі. Стан душі героя оповідання «Гинуть мрії» передається автором через алегоричне зіставлення боротьби різних сил природи з внутрішньою боротьбою «Я», тобто самого героя. Мотив роздвоєності «Я» складає важливу домінанту монологу, який утілено в типовій для імпресіоністичної поетики формі «потоку свідомості», в якому переважає розірвана оповідь, як форма і засіб вияву внутрішнього конфлікту.

Яскравою стилістичною рисою імпресіоністичної прози В. Леонтовича виступає також і невласне пряма мова. На відміну від Ольги Кобилянської, Марка Черемшини, Грицька Григоренка, Леся Мартовича, письменник порівняно мало вдається саме до такого прийому 
моделювання внутрішнього світу персонажів. В. Леонтович здебільшого надає перевагу внутрішнім монологам героїв. Утім, домінування невласне прямої мови простежується в моментах зіткнення між думкою і почуттям, але не $\epsilon$ визначальною рисою поетики творів письменника. («Вигнанці», «Гинуть Мрії», «Ворохобня»). Внутрішні монологи $є$ своєрідними формами коментування (а в окремих випадках фіксації) того, що висловлюється іншими персонажами. Невласне пряма мова майстерно трансформується в пряме мовлення персонажів, яке суттєво відтворює складний перебіг їхніх думок, розумово-чуттєвих процесів.

Сказане вище підтверджує наявність у прозі В. Леонтовича вже проаналізованих нами особливостей імпресіонізму. Письменник осмислював проблеми сенсу буття, також і феномен смерті як моменту й засобу випробування сутності людини. Автор повісті «Ворохобня» прагне утвердити перевагу гуманістичного начала в структурі особистості над усіма іншими.

У змодельованих письменником сюжетних колізіях випробовуються душевні якості персонажів, міцність їх філософських концепцій. Поразка головного героя із твору «Ворохобня» Опанаса Порубайка та є не просто моментом розв'язання екзистенційної проблеми особистості, а сприймається як крах власних ідей, носіями яких вони виступають.

Отже, аналіз художніх особливостей ранніх і більш пізніших творів письменника дозволяє зробити висновки про поступову еволюцію від традиціоналістично-реалістичної манери письма до творів 3 яскраво вираженою імпресіоністичною домінантою.

\section{СПИСОК ВИКОРИСТАНОЇ ЛІТЕРАТУРИ}

1. Агеєва, В. Українська імпресіоністична проза / В. Агеєва. - К., 1994. - 159 с.

2. Кузнецов, Ю. Імпресіонізм в українській прозі кінця XIX - початку XX ст. / Ю. Кузнецов. - К. : Зодіак-ЕКО, 1995. - 304 с.

3. Леонтович, В. Дитячі і юнацькі роки Володі Ганкевича: повість-хроніка у двох частинах / В. Леонтович // Леонтович В. М. Зібрання творів : в 4-х т. - К. : Сфера, 2005. - Т. 3: повість, спогади. - С. 10-168.

4. Леонтович, В. Ворохобня : оповідання / В. Леонтович. - К., 1930. - Т. II. -96 с.

5. Леонтович, В. Спогади про діячів мого покоління / В. Леонтович // Тризуб. 1928. - № 27. - 5.VII. - C. 8-12.

6. Леонтович, В. Листи / В. Леонтович // Українське слово. - 1996. - 19 вересня. C. 12.

7. Леонтович, В. М. Листи до В. Лукича. Відділ рукоп. Інституту літератури ім. Т. Г. Шевченка НАН України. - фонд № 61 /683, 684, 689; од. Зб. 906; 1884-1940 pp.

8. Погребенник, Ф. Володимир Леонтович / Ф. Погребенник // Українська мова та література. - 1996. - Число 15. - С. 1-8. 
9. Франко, І. Зібр. творів : у 50-ти т. / І. Франко. - К. : Наук. думка, 1976-1986. T. 30. - C. 344-538; T. 33. - C. 174; T. 34. - C. 363; T. 35. - C. 108, 230, 91-112; T. 41. - C. 47-152.

Стаття надійшла 31.03.2016 року

УДК 398(477)

Наталія Сивачук

(Умань, Україна)

\section{ОБРАЗ РУСАЛКИ В КОНТЕКСТІ ФОЛЬКЛОРНОЇ СЕМІОСФЕРИ УКРАЇНЦІВ}

У статті розглядається образ русалки в українському календарно-обрядовому фольклорі. Порушуються питання ритуально-міфологічної основи свята русалій, генези образу русалки, його полісемантичності $i$ поліфункціональності. Автор звертає увагу на світоглядно-духовну та художньо-семантичну його суть. Образ русалки розглядається у зв'язку з системою магічно-релігійних заборон на певні дії, з порушення яких на людину чатує страшна кара. В основі иьього образу лежить феномен табу, щзо спонукало людину вгамовувати свої інстинкти, поставити між собою і своїми природними потягами систему моральних норм.

Ключові слова: русалка, календарно-обрядовий фольклор, поліморфізм, амбівалентність, полісемантичність, табу, архетип, сакральні ключі, світоглядні уявлення, лімінальний знак, русальний тиждень.

Сивачук Н. Образ русалки в контексте фольклорной семиотики украинцев.

В статье рассматривается образ русалки в украинском календарно-обрядовом фольклоре. Анализируются вопросы ритуально-мифологической основы праздника русалий, генезис образа русалки, его полисемантичности и полифункциональности. Автор обращуает внимание на его мировоззренчески-духовную и художественносемантическую суть. Образ русалки рассматривается в связи с системой магикорелигиозных запретов на определенные действия, за нарушение которых человека ожидает страшная кара. В основе этого образа лежит феномен табу, что требовало от человека сдерживать свои инстинкты, ставить между собой $и$ своими природныли склонностями систему моральных норм.

Ключевые слова: русалка, календарно-обрядовый фольклор, полиморфизм, амбивалентность, полисемантичность, табу, архетип, сакральньее ключи, мировоззренческие представления, лиминальный знак, русальная неделя.

Syvachuk $N$. The image of mermaid in the context of Ukrainian folk semiotics.

The image of a mermaid in Ukrainian calendar-ceremonial folklore was lighted up in the article. The ritual and mythological foundations of the holiday Rusalii were discussed, as well as Ukrainian ideas about mermaid, the image of mermaid and its genesis, its polysemantic and multifunctional. The author draws the attention to the ideological, spiritual, artistic and semantic core of the image of a mermaid. The image of a mermaid was considered in the connection with the system of magic-religious prohibitions on certain acts and there violation was coming with terrible punishment. The source of the mermaid 